\title{
OCEANIC VERSES OF THE QUR'AN AND THEIR POINTERS TO TECHNOLOGICAL SOLUTIONS
}

\author{
Mifedwil Jandra, Anhar Anshori, HM Kholili, Arif Rahman \\ Faculty of Islamic Studies, Universitas Ahmad Dahlan Yogyakarta \\ Faculty of Da'wah and Communication, Sunan Kalijaga State Islamic \\ University Yogyakarta. \\ Faculty of Islamic Studies, Universitas Ahmad Dahlan Yogyakarta \\ Email : mifedwil.jandra@pai.uad.ac.id, anharanshori52@gmail.com, \\ hmkholili2018@gmail.com, arif.rahman@pai.uad.ac.id
}

\begin{abstract}
This study aims to explore the phenomenon of the ocean recited in the verses of the Quran such as, firelenergy in the ocean, two oceans that do not blend, deep darkness of the ocean, sea boundary, oceanic layers, and the abundant wealth of the sea for humanity. This article focuses first on the semantic aspects on oceanic verses as revealed and found in 42 verses in the Quran and then how these verses could be used as guidance for technological solutions. The study uses the method of interpretation of bir rakyi or interpretation within reason using the scientific method. Modern semantic scientific methods, ontology, and the categorization of verses are used for further understanding and developing a framework for further study in developing a foundation for Islamic Marine Knowledge. The study findings indicate that the knowledge of layers in the seawater column, as mentioned in the Quran, could be a blessing for Muslims to be inspired and guided to find more discoveries and benefits of this water layer phenomenon. These ancient manuscripts are relevant to the challenges of modern civilization, such as food and energy security and environmental control. There are clues in these oceanic verses about technological solutions to the existing and future humanitarian problems, which Muslims can use as a divine guidance.
\end{abstract}

Keywords: Ocean Verses, Bahr, Knowledge of Islamic Ocean Introduction.

HERITAGE OF NUSANTARA: INTERNATIONAL JOURNAL OF RELIGIOUS LITERATURE AND HERITAGE | 1 


\begin{abstract}
Abstrak
Artikel ini berfokus pertama pada aspek semantik, ontologi, dan kategorisasi dari ayat-ayat samudera sebagaimana diungkapkan dan ditemukan dalam 42 ayat dalam Al Qur'an dan kemudian pada bagaimana ayat-ayat laut yang dipilih sebagai petunjuk untuk solusi teknologi. Kajian ini bertujuan untuk mengetahui fenomena lautan dalam ayat-ayat Al-Qur'an dengan menawarkan interpretasi alternatif tentang beberapa masalah, termasuk; api / energi di dalam lautan; dua samudra yang tidak berbaur; kegelapan samudera yang dalam; batas laut; lapisan-lapisan samudera; dan kekayaan berlimpah dari lautan bagi umat manusia. Kajian menggunakan metode Tafsir bir rakyi atau tafsir dengan akal menggunakan metode ilmiah. Metode ilmiah modern semantik, ontologi, dan kategorisasi dari ayat-ayat digunakan untuk pemahaman lebih lanjut dan menciptakan kerangka kerja untuk studi lebih lanjut dalam mengembangkan landasan untuk Pengetahuan Kelautan Islam. Hasil kajian menunjukkan bahwa pengungkapan lapisan yang ada di kolom air laut; sebagaimana disebutkan dalam al-Qur'an, dapat menjadi berkah bagi umat Islam kemudian menjadi terinspirasi dan dibimbing untuk menemukan lebih banyak temuan dan manfaat dari fenomena lapisan air ini. Temuan pada analisis ayat-ayat kelautan ini dipostulatkan sebagai wahyu kuno untuk tantangan paling signifikan peradaban modern: solusi langsung untuk keamanan pangan dan energi; kesehatan \& obat-obatan; transportasi dan mobilisasi barang; manajemen lingkungan; dan kelahiran disiplin baru Pengetahuan Laut Islam. Ada petunjukpetunjuk dalam ayat-ayat samudera ini tentang solusi teknologi untuk masalah umat manusia yang ada dan yang akan datang, yang pada akhirnya umat Islam dapat menggunakan petunjuk ilahi ini.
\end{abstract}

Kata kunci: Ayat Kelautan, Bahr, Pengetahuan Laut Islam 


\section{Introduction}

The Kawniyah verses are known as empirical universe that we can observe, touch, measure and live in it. This Kawniyah verses can also be addressed to verses that are literally inscribed in the al-Qur'an and specifically mention or reveal about the empirical universe, but not the aspects of Islamic law or shar' $i$ from halal and haram, and all of the shar iyyah Islamic law. Therefore, within the discourse of aqidah or the fundamental of faith, there are verses of Kawniyah, which means: 'the signs given by Allah in the universe, as the 'sign' of the existence of Allah, the sign of the Most Merciful, the sign of the Most Exalted, and all of the sign of Allah's presence.

In the al-Qur'an, some verses called Kawniyah verses as called by Islamic Scholars. Al-Qur'an consists of 6236 verses, reveals all aspects of human life, as well as inspiring solutions based on alQur'an. Those explanations, also known by scholars as the kawniyyah verses. Shihab mentioned that there are more than 750 verses describing planetary processes followed by exposure of the universe with its phenomena. This figure does not include verses that explain it in between the lines or with symbolic terminology. (Shihab, 1997) There are 42 words of "ocean" in the al-Qur'an, with various topics and subtopics in regard to the ocean. It is not merely mentioned 'the ocean' in the historical nor symbolic contexts. Or about the oceans that can grow their water because of the impact caused by planetary phenomena, what happens to the orbiting sun and sky openings (Djamil, 2004). The high frequency of the appearance of oceanic words in the Koran is very impressive because all the revelations from 
the oceanic verses are in Mecca and Medina in the middle of a desert far from the ocean.

The 'oceanic verses' not only reveal how the prophet Musa (PBUH) split the ocean, or when the prophet Musa (PBUH) opened the ocean to let him and his exodus followers pass and escape from Pharaoh but also reveals about how we can discover fire or energy from the ocean deep. about the oceans that can grow their water because of the impact caused by planetary phenomena, what happens to the orbiting sun and sky openings. (Djamil, 2004) Or about the ocean that may sprout its water due to the impact exposed by the planetary phenomenon, happens to the orbiting sun and the opening of the sky. (Djamil, 2004) The high recurrence of the oceanic words in the al-Qur'an is impressive as all revelation of those oceanic verses were in Mecca and Medina in the middle of a desert far away from the ocean. Secondly, the frequency of the 'oceanic' words is outnumbering the rate of appearance of 'religious' wording and terminology such as the word zakat, tahajud, tayyiban, mutaharah, etc. The frequently spoken words recorded and searched using the following index in scripted in the al-Qur'an. The method of finding those words in the verses is using words-index and mathematical formula, (Audah, 1992); (Badawi \& Haleem, 2008) dan Corpus Qur'an. (Dukes, 2011)

The earth is $72 \%$ covered by ocean, and only $28 \%$ land mass. Indeed most of that water is very deep, average water depth is around 3800 meter, while the average land altitude is only around 400 meter. Maybe, this planet is rather called "Ocean" rather than "Earth". If we leveled up all the land mass all over the world, the planet would be a water ball with water thickness around 3400 meter thick. (Djamil, 2004) Even if we compare it to the tallest volcano on earth, Mauna Kea 
Volcano which measured 10,200 $\mathrm{m}$ from its foot of the slope, it still less than the deepest of the ocean Mariana Trench, which is 10,860 meters. (Engel, 1979; Talbot \& Stevenson, 1991)

There are 42 occurrences of word "ocean / sea" in the Qur'an. (see Table 2). This high frequency occurrence is relatively impressive firstly, in a sense that the Qur'an revealed in a place far from ocean, secondly, it outnumbers other words that presumably very common (such as zakat, tahajjud, tayyiban, mutaharah, etc.). Word counts referred to Audah (1992), Badawi \& Haleem (2008) and Corpus Qur'an (Dukes, 2011). (see Table 1)

\begin{tabular}{|l|l|l|}
\hline \multicolumn{1}{|c|}{ Words } & \multicolumn{1}{|c|}{ Meaning } & $\begin{array}{l}\text { Number of } \\
\text { Occurrence } \\
\text { throughout } \\
\text { Al Qur'an }\end{array}$ \\
\hline Sama ‘a, sama i, sama 'u. & Sky / Heaven & 120 \\
\hline $\begin{array}{l}\text { Anhara, anharu, (47), } \\
\text { Anharan (3), Naharan (1) }\end{array}$ & River & 51 \\
\hline $\begin{array}{l}\text { Syamsa, syamsi, syamsu } \\
\text { (32), syamsan (1) }\end{array}$ & Sun & 33 \\
\hline $\begin{array}{l}\text { Qamara, qamari, qamaru } \\
(26), \text { qamaran (1) }\end{array}$ & Moon & 27 \\
\hline Barri, barru (1) & Land & 13 \\
\hline Tura, turi & $\begin{array}{l}\text { Mount (Sinai), large } \\
\text { mountain with trees }\end{array}$ & 10 \\
\hline Rowasiya & Mountainous & 9 \\
\hline Jabala, jabalin & Mount, hill without tree & 6 \\
\hline
\end{tabular}

Table 1: Random 'tabi' $i$ ' or natural phenomenon related words occurrence

Interesting to ponder, whether there is correlation between the frequency of occurrence of a word in the Qur'an and the value of information contain in this word. For instance, sholat tahajud or early day prayer, known as very importance and valuable deed to conduct 
for muslim, but the word of 'tahajjad' or salat tahajud appears only once in the whole Qur'an.

\section{Result and Discussion}

\section{What is the Oceanic Verses?}

Oceanic Verses, coined by authors, are selected verses in the Qur'an that contain word of 'ocean' and 'sea' in several terminology like baḥr, baḥri, baḥru, biḥar, baḥrayn, baḥran, bahrayni (see Table 2). 'Sea' or' ocean' were also referred in several other verses but neither mentioned in those words, instead by word Yammi(u), suffix "hi", and suffix "na/in". Attentions were given on the Semantics, Ontology and Categorization aspects of oceanic verses as revealed and found in 42 verses in Al Qur'an. Word 'baḥr' and its variation in those verses were studied semantically first. Key words surrounding the 'baḥr' words were analyzed and cross checked with relevant verses to grasp the closest message and guidance. Later, ontologically study the nature of existence of the oceanic verses, their realm in the knowledge system, and Categorization of its existence and their relations.

The meaning of the words in the study is based on the ArabicEnglish Dictionary of Qur'anic Usage by El Badawi. (Badawi \& Haleem, 2008) The word 'sea' or 'ocean' in the Qur'an's translation were based on the triliteral root word bāḥārā (ب) occurs 42 times in the Qur'an, in two derived forms: 41 times as the noun baḥr ( and 1 time as the noun bahịrat (פ) as ocean, sea, great river, great expanse of water, lake, generous person, great knowledge; to slit an animal's ear in ritual. It occurs 33 times in Al Qur'an in 3 different vowels. Bahr ended without vowel occurs in 7 
verses, baḥr ended with vowel 'i' occurs in 23 verses, baḥr ended with vowel ' $u$ ' occurs in 3 verses where in verse 18:109 the bahru word occurs twice.

The word bihārr, is a noun, plural of baḥr, meaning "all oceans all over the world." Bihar occurs 2 times in Al Qur'an. When the word is used, it is indicating that the oceans meant in these verses are explaining phenomena that apply to whole oceans all over the planet earth. The two verses using the word have broader and allencompassing ocean compares to the rest of ocean word in many other verses. These two bihār, specifically in the context of the Qiyāmah (doomsday) prophecy.

\begin{tabular}{|c|c|c|c|c|}
\hline Source & $\begin{array}{l}\text { Verses in Al Qur'an where } \\
\text { the Ocean/Sea word occurs }\end{array}$ & $\begin{array}{l}\text { Numbers of } \\
\text { occurrence } \\
\text { in Al } \\
\text { Qur'an }\end{array}$ & $\begin{array}{l}\text { Transliter } \\
\text { ation }\end{array}$ & Word \\
\hline 1 & & 42 & & $\begin{array}{l}J / \mathrm{C} / \mathrm{u} \\
\text { root } \\
\text { word }\end{array}$ \\
\hline & \multicolumn{4}{|c|}{5 forms occur throughout $\mathrm{Al}$ Qur'an } \\
\hline $1,2,3$ & $\begin{array}{l}(2: 50) ;(2: 164) ;(5: 96) ; \\
(6: 59) ;(6: 63) ;(6: 97) ; \\
(7: 138) ;(7: 163) ;(10: 22) ; \\
(10: 90) ;(14: 32) ;(16: 14) ; \\
(17: 66) ;(17: 67) ;(17: 70) ; \\
(18: 61) ;(18: 63) ;(18: 79) ; \\
(18: 109) \text { twice;(20:77); } \\
(22: 65) ;(24: 40) ;(26: 63) ; \\
(27: 63) ;(30: 41) ;(31: 27) ; \\
(31: 31) ;(42: 32) ;(44: 24) ; \\
(45: 12) ;(52: 6) ;(55: 24)\end{array}$ & 33 & $\begin{array}{l}\text { Baḥr, } \\
\text { Baḥri, } \\
\text { Baḥru }\end{array}$ & \\
\hline 3 & $\begin{array}{l}(2: 50) ;(7: 138) ;(10: 90) ; \\
(16: 14) ;(26: 63) ;(44: 24) ; \\
(45: 12)\end{array}$ & 7 & Baḥr & \\
\hline 3 & $\begin{array}{l}(2: 164) ;(5: 96) ;(6: 59) ; \\
(6: 63) ;(6: 97) ;(7: 163) ; \\
(10: 22) ;(14: 32) ;(17: 66) ; \\
(17: 67) ;(17: 70) ;(18: 61)\end{array}$ & 23 & Baḥri & \\
\hline
\end{tabular}




\begin{tabular}{|c|c|c|c|c|}
\hline & $\begin{array}{l}(18: 63) ;(18: 79) ;(20: 77) \\
(22: 65) ;(24: 40) ;(27: 63) \\
(30: 41) ;(31: 31) ;(42: 32) \\
(52: 6) ;(55: 24)\end{array}$ & & & \\
\hline 3 & $(18: 109)$ twice and $(31: 27)$ & 3 & Bahru & \\
\hline 3 & $\begin{array}{l}(55: 19) ;(25: 53) ;(18: 60) ; \\
(27: 61)\end{array}$ & 4 & Bahrainy & بَحَر \\
\hline 3 & $(35: 12)$ & 1 & Bahrani & \\
\hline 1,3 & $(81: 6),(82: 3)$ & 2 & Bihar & \\
\hline 3 & $(31: 27)$ & 1 & Abḥur & \\
\hline 1,3 & $(5: 103)$ & 1 & Bahiyratin & تَ \\
\hline & \multicolumn{4}{|c|}{$\begin{array}{l}\text { 'Sea' or' ocean' also were meant in several other verses but neither } \\
\text { mentioned in such "bahr/i/u", "bahrayn", nor "abhur" words }\end{array}$} \\
\hline $1,3,4$ & $\begin{array}{l}(7: 136) ;(20: 39) \text { twice; } \\
(20: 78) ;(20: 97) ;(28: 7) \\
(28: 40) ;(51: 40)\end{array}$ & 8 & Yammi(u) & 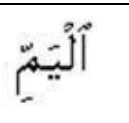 \\
\hline 4 & $(17: 69) ;(42: 33)$ & 2 & Suffix “hi" & $\tilde{z}$ \\
\hline 4 & $(43: 55) ;(21: 82) ;(18: 86)$ & 3 & $\begin{array}{l}\text { Suffix } \\
\text { "na/in", }\end{array}$ & $\dot{v}$ \\
\hline \multicolumn{5}{|c|}{$\begin{array}{l}\text { Sources: } \\
\text { 1.Badawi, Elsaid M. And Muhammad Abdel Haleem; AF } \\
\text { DICTIONARY OF QUR'ANIC USAGE, } 2008 \\
\text { 2. Corpus Qur'an, Kais Dukes, http://corpus.Qur'an.com } \\
\text { 3. Konkordasi AlQur'an, Ali Audah, } 1990 \\
\text { 4.AlQur'an Web: http://alQur'an.babinrohis.esdm.go.id/ }\end{array}$} \\
\hline
\end{tabular}

\section{Table 2: Statistic of word Oceanic Verses}

Interestingly and phonetically beautiful, the words that follow bihar in these two verses differ just by single letter, ' $\mathrm{F}$ ' and ' $\mathrm{S}$ ', but have many differences; Sujirat (QS At Takwīr 6) and Fujirat (in QS Al Infitạar 3). The value that we can derive from these two verses are the Qiamat (doomsday) prophecy indicated at least at two different episodes: The first episode (At Takwīr), is when the bihār is sujirat, the ocean is experiencing sea level rise phenomenon due to the collapse of the solar system. the next episode (Al Infițār) is when the bihāar is 
fujirat, the ocean is experiencing loss of gravity or escaping earth surface phenomenon due to the collapse of the galactic system, the universe.

The word bahrayni, "two oceans" or "two seas", or the two bodies of flowing water, occurs in 5 verses. The verses use the word two seas in the contexts of prophetic history and of sustenance. The prophetic history about prophet Moses wished to meet prophet Khidir as in verse Al Kahfi 18:60 (and Al Kahfi 61 use the word bahri syaraban, but translated as two ocean). In the context of sustenance due to the natural phenomena of two oceans, the word reveals in four verses: Al Furqān 25:53, An Naml 27:61, Fațīr 35:12 and Ar Raḥmān $55: 19$.

The word bahīratun, means "the one with slit ear" camel. The meaning seem irrelevant with the majority term of ocean and sea as the term is used for camel. But it may be relevant if we take "slit" or "tear" or "opening". As "the opening" can be associated with opening of the earth surface to create a new sea or ocean. At present there is earth opening phenomenon that can be observed on land, which is in afar region of Ethiopia in the horn of Africa. This is a modern example on land. Beneath the sea on the ocean floor at thousand meters depth below the sea water surface, the oceanic crusts of the outer most layer of earth are continuously cracking and opening. The birth of new sea floors and additional seas occurs at the tectonic plate boundaries around the globe.

\section{Ontology of the Oceanic Verses}


In philosophy, where ontology initially introduced, it defined as systematic account of existence (Gruber, 1995). Ontology, from the Greek's onto which means "being”, "that which is" or "word"; andlogia, logos, means "science", "study", or "theory". Dagobert (1976) in Yusoh \& Muhammad (2012) Therefore, ontology is the philosophical study of the nature of being, existence, or reality. It may be understood as well as the basic categories of the existence of things and their relations to other things in space and time.

In the discipline of Artificial Intelligent, ontology is known as an explicit specification of a conceptualization. "Ontology refers to the subject of existence. Ontology is often confused with epistemology, which is about knowledge and knowing." (Gruber, 1995) The third definition of ontology is a body of knowledge describing some domain, typically common sense knowledge domain. These definitions view ontology as an inner body of knowledge, not as the way to describe the knowledge. (Obitko, 2007) As this is explicit specification, the concept of bahr in several oceanic verses in the Qur'an therefore can be represented explicitly as centerpiece within the knowledge system and related to other concept which are better to be represented in the graphical form. (see Chart 1)

Why do we need to understand the word in ontological framework? We want to see whether the oceanic verses have specific concept that their existence in the Qur'an has significant information value which later the oceanic verses established themselves as foundation for further understanding and application of the concept. The ontology chart of bahr or ocean in the Qur'an below shows the existence of bahr in among the clouds of other concepts and its relationship. 
Bahr existence within the Qur'an, is not merely in the historical context which reveals the story of Prophet Moses crossing the ocean; the Pharaoh's drowning and its preservation of its body; Noah's ark; and the condemnation of the Israelites clan who violated the Sabath rules. (See Table 4)

The oceanic verses reveal the subjection and facilitation of the ocean for humankind, therefore humankind may learn, use the opportunity and harvest the bounty from the ocean. The syariat or legal implication aspect of the bahr toward the human society needs to be studied. Is the information provided in An Nahl 16:14 about various bounties from the ocean merely show of Allah greatness, a guarantee of facilitation, guidance, or further as commandment to humankind to explore and exploit the ocean to sustain their life in this earth? As the fiqh of cleanliness and food from the sea have established, other aspect such as fiqh on seeking bounty in the ocean through exploration and responsible exploitation must also be established.

The understanding of bahr from the revelation leads us to broader understanding extended to the scientific and technological applications that humankind can benefit from the existence of ocean. (See Table 4) The method or ways to utilize it need to be learnt and developed systematically. Finally, humankind is taught to appreciate (syukür) of the existence of oceans and its various phenomena and bounties. 


\section{Ontology of Islamic Marine Knowledge}

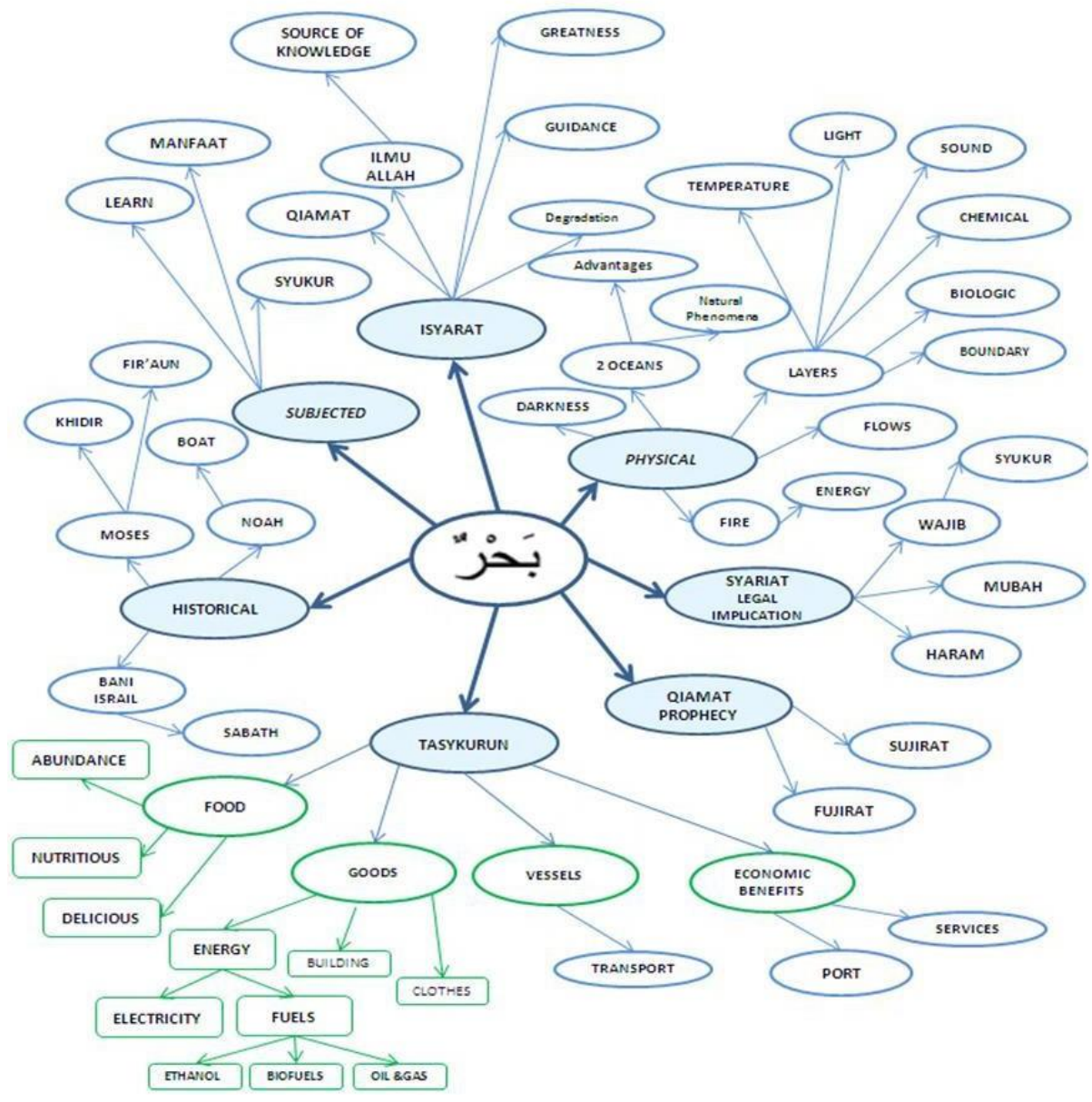

Chart 1: The ontology chart of bahr or ocean in the Qur'an

\section{Selected Oceanic Verses as Pointers to Technological Solutions}

There are selected Qauliyah verses as literally written which consist of group of verses: Ar Raḥmān 19 - 22, At Takwīr 1 - 6 and Al Infitậr 1 - 3, and singular verse: At Ṭūr 6, that have been studied using 
parallelistics method with Kawniyah verses or the realistic world. Most of the explanations by the Islamic scholars on those verses were emphasized on the language aspect, on the implication to the faith and rituals. While one of them such as Tafsir al Tustari, elaborates the explanation on the philosophical aspect and analyzes those verses as their symbolical means. Paralellistic method used in analyzing the verses offers an alternative to deepen the faith, depicts the miracles, and to find directive on technological solutions as the application to the society. In deepening the faith, the parallelistics approach would reveals on how the dictions or the selection of word in expressing a message is so precise, unique, and truly show the miraculous significance that we can witnessto this day. Such selection of words, and/or metaphors using the 'oceanic' expression and phenomena while the verse were starkly revealed in the midst of Arabian desert in the six century, hence vividly clear in using the term in the context of what todays scientists just learnt it, is certainly worth a miracle. While the technological solutions offered to the modern society to address their problems have led to the directions of new discoveries, solutions, innovations which in turn will bring the whole society, not only Muslims, to reach levels of civilized achievement and prosperity distanced from kufur or denials to the truth of Allah.

The analysis of these oceanic verses postulated that ancient revelation of the Qur'an is solution for modern civilization's biggest challenges: food and energy security; health \& medicine; transportation and mobilization of goods; and environmental management. (see Table 4) Here is a selection verses that show how 
the revelation is all encompassing throughout the discipline and aspect of life. Selected oceanic verses are as follow;

Subjugated ocean is intendedfor human food, products, ship transportation and sustenance. Subjugated ocean created by Allah SWT is for the sake of providing His creation with enough food, various products, transportation and sustenance as mentioned in verse An Nahl 16:14 ; "And it is He who subjected the sea for you to eat from it tender meat and to extract from it ornaments which you wear. And you see the ships plowing through it, and [He subjected it] that you may seek of His bounty; and perhaps you will be grateful." (International, 1997) This is a very comprehensive and complete verse regarding ocean exploration and exploitation. The verse should encourage Muslims to take advantage of the subjected ocean for their benefit is many aspect of life: food, utility, something to wear (from clothes, materials, energy, building materials, up to jewelry), ships, bounty from sustenance and services over the ocean.

Out of the ocean, mankind may extract through elaborative process, hence Allah uses the word 'tastakhriju' to give emphasize rather than the lighter word like 'tukhriju'. This elaborative process may be illustrated with the process of most of our goods, which are products out of ocean. Our building for instance, built with cement concrete. Cement material is produced from mixture of limestone, silt, kaolinitic clay and some additives. The main component is the limestone mined from the hills, but actually originated from metamorphosed rock from coral reef in the ocean.

Another example, our nice lightweight and comfort clothes are made of polyester that produced from petrochemical with natural gas as the feedstock. The natural gas, is the product of decomposed marine 
fossils that undergone maturation over million years of geochemical and geological processes.

Therefore humankind should be grateful to this ocean subjection and facilitation by Allah as the suggestion was used to conclude this verse. Interestingly, this An Nahl 16:14 verse concluded with a suggestive closing sentence: "and perhaps you will be grateful" which is repeatedly rephrases in similar oceanic verses. Hence, the bounty given by Allah in the ocean is something for humankind to utilize and be grateful upon it, rather than just contemplate them and praising the Greatness of Allah such as repeatedly mentioned in the astronomical phenomenon verses.

\section{Fire or Energy or Heat within the Ocean}

Fire or Energy or Heat within the ocean are mentioned in verse At Țur 52:6; "And [by] the sea filled [with fire]." (International, 1997) Initially the verse seemed paradox as the sea is aquatic world which oppose or extinguish fire. But as the context of the verse in between materialize facts, verse 1: "the Mount (Sinai)", 2: "the Book Inscribed", 3: "parchment spread open", 4: "the House (Ka"ba) that is visited", and 5: "the heaven raised high"), all are something that real today in this world, as Allah swear and affirm upon them.

There are several meaning of translation of the word "masjūr" in the verse At Țur 52:6, which converged to the understanding of the hydrokinetics or the movement of the water body that occurs in the "bahri" or ocean. Hydrokinetics are all the movement of the body of water such as waves, ocean swell, ripples, current, tides, tidal currents, flows, et cetera. This hydrokinetics is suggested as an alternative to the 
existing translation that says: "laut yang di dalam tanahnya ada api", or "the ocean in which there are fires under its seafloor". This is translated from the Team of Ministry of Religious Affair Republic Indonesia such as "demi lautan yang penuh gelombang" or "in the name of the ocean that filled with waves or swells." (Lajnah Pentahshih Al-Qur'an Departemen Agama Republik Indonesia, 2002) Tafsir al-Jalalayn, (Al-jalalayn, 2012), does not elaborate but rather simply writes: "and the swarming sea: that is to say, the one that is filled".

More elaborative but seem mixing the event with the future prophecy of what will happen in jahannam hell is shown by Tafsir Ibn 'Abbas. ('Abbas, 2012) The tafsir Ibn 'Abbas is: ... Through it Allah will bring to life, on the Day of Judgment, all created beings. It is also said that 'the sea kept filled' is a hot sea which will become fire and will be opened in jahannam hell on the Day of Judgment. Allah swore by all these things." We understand that when Allah Swears, the objects are real and they are something for humankind to witness, rather than the prophecy that will be shown later. So mixing objects like this may cause confusion contrary to the objective of the swearing. Application wise, this At Țur 52:6 verse should inspire Muslims to explore the vast ocean for possible energy resources which may come in conventional or unconventional ways.

\section{Layers and the Darkness of the Ocean Deep}

Layers and the darkness of the ocean deep as mentioned in verse An Nūr 24:40 as translated; "Or [they are] like darknesses within an unfathomable sea which is covered by waves, upon which are waves, over which are clouds - darknesses, some of them upon others. When 
one puts out his hand [therein], he can hardly see it. And he to whom Allah has not granted light - for him there is no light." (International, 1997)

Though the ocean is part of parable in describing a person who did not get guidance from Allah, but the reality that was revealed was very valuable information much ahead of the time of revelation. Even to today's scientific standard, the darkness and layers of the oceans still understudied and minimally utilized.

Layers in the ocean water column is phenomena that only recently human being started to understand and began to get benefit of this layers. Layers are in the form of at least physical, chemical, and biological. In the physical layers, scientists began to understand layers of ocean currents, density, salinity, temperature, pressure, speed of the traveling sound waves, et cetera. For temperature for instance, the warmest water stay at the top and cooler at the lower part. But when it reach freezing point of 0 degree Celcious, the frozen water will surface and float on the top of the water leaving the heavier and warmer water of 4 degree Celcius stays at the lowest part of the water column. This anomalous layers of water is a gift from Allah for the faunal being in the water column to stay alive during the winter season.

The layers of combination of density, pressure and temperature, create a condition of anomalous layer at about 500 meter water depth which act as sound amplification layers where the sound occurs at that water column may travel very long distance across the vast ocean. Scientist call this layer as SOFAR channel, where studies have been conducted to understand how sea mammals like whales can communicate each other, warn each other or listen a tsunami or ocean 
obstruction thousand miles away. The Navy of the superpowers is competing each other to utilize this SOFAR channel to develop remote sensing instrument to detect the enemy intruders.

With this revelation of the existing layers in the ocean water column as mentioned in the al-Qur'an, Muslims should be blessed to be inspired and guided to discover more finding and benefit from this water layers phenomena.

\section{The Ship Building Technology as Reveals, Divine Instruction and Supervision}

It is mentioned in verse Hūd 11:37 as translated; "And construct the ship under Our observation and Our inspiration and do not address Me concerning those who have wronged; indeed, they are [to be] drowned." (International, 1997) It is very interesting to note how this initial ship building is actually taught as revelations. Today, humankind takes the ships shape and design for granted without realizing how the solid material of ship can float, how the ship can carry huge volume, and how immense weight can be lifted over the water. The designs of ship, the Noah's Ark then, were a divine revelation. It is which probably the only transportation technology that directly revealed by the Creator of this universe and its initial construction were supervised directly by Allah, as mention in this verse.

May be most people taken water-floating vessel or ships for granted without realizing how this floating vehicle is very robust, powerful and useful. It is a logical consequence that the blessing of Allah on the transportation being the ship, not the desert going caravan 
nor carriage nor even train, as $72 \%$ of the earth is covered by ocean. Basically, earth is a watery planet that water-floating vessel is ultimate necessity for transportation of humans and goods.

Water-floating vessel is not only in the form of ships. Nowadays we witness how the largest transportation vehicle on earth is floating on the ocean across the globe in very reasonably fast and efficient. Oilrig platform nowadays is a small floating town by itself, weighted more than 100 thousand tons, it float on the water cater for hundreds of people working and living there. A cruise has more than 15-storey tower similar to a cluster of hotel in the downtown cities, but moving freely from port to port in a matter of days. A super container cargo vessel can lift 5000 cars at once and transport it from Korea to Europe in one go that for similar lifting by trains over the Goby desert from China to Russia will need to travel in hundreds of return trips.

Allah SWT also Directs human being to create and innovate vehicle similar to the work of floating ship loaded with full passengers as mentioned in the surah Yāsīn 36: 41- 42: "And a sign for them is that We carried their forefathers in a laden ship. and created for them similar things to ride." This should be a valuable clue for Muslim inventors to invent future transportation system that taking benefit of floating vehicle over the liquid at speed and energy-efficient manner.

The two the oceans that do not merge with the boundary of the two oceans that bring abundance wealth from ocean to humankind as mentioned in verse Ar Raḥmān 55:19-22; "He released the two seas, meeting [side by side]; Between them is a barrier [so] neither of them transgresses. So which of the favors of your Lord would you deny? From both of them emerge pearl and coral." (International, 1997) The 
condition occurs between the converging two seas or oceans bringing a great quantity and quality of condition that the Qur'an metaphorically using the symbol of 'pearl and coral' that may emerged.

The boundary of the two oceans may be termed either in microscopic scale or in macroscopic scale. The boundary can be either in the horizontal juxtaposition where one kind of ocean sits side-byside next to the other kind of ocean, or in the vertical juxtaposition where one kind of ocean lays on top of another kind of ocean. So far, many literature mentions this boundary as rather in the horizontal juxtaposition, and pointing the different color change as the boundary of the two ocean, such phenomena observed in the ocean zone between Atlantic and Indian ocean near the bottom tip of Africa. Hence the vertical boundaries also exist in many different forms like layers of physical, chemical, biological and oceanological boundaries.

The authors like to extend the boundary in term of macroscopic scale such as the boundary between the Indian Ocean and the Pacific Ocean, which is located in the Indonesian archipelago, as the general location zone of this macroscopic boundary. This boundary zone creates abundance of blessing, as may be termed as the "lu'lu wal marjan". This zone, creates the most complete ocean biodiversity on earth. The zone is home of more than 50\% fish species of the whole world, home of about $75 \%$ of coral reef of the whole world, home of the most complete seaweed and seagrass on earth. Such oceanic biodiversity abundance made this Indonesian archipelago and its adjacent waters called the Coral Triangle of the world.

The written Qauliyah verses in the group of verses Ar Raḥmān 55: 19-22, as written there "two oceans", "the boundary between the two seas", "the boundary that impenetrable" and "lu'lu wal marjān", 
can be found their parallel in the real Kawniyah verse that experienced and observable in the real oceans. Hence in those ocean boundaries humankind may harvest privilege, benefits in abundance as the Gift from Allah SWT. No wonder, the verses here is peppered with Allah's repeated challenge: "So which of the favors of your Lord would you deny?"

\section{Prophecy the End of the World as Seen on the Effect of the Ocean}

Two clusters of surah At Takwīr 81:1-6 and Al Infițār 82:1-3 states about the two catastrophic event during the kiamat or end of the world. The effects on the ocean indicated as the solar system and planetary constellation undergone chaotic events. At the first cluster of ayat as mentioned in At Takwir 81:6, as the sun being folded and becoming smaller and denser at one phase of the doomsday, the planet in the solar system falls, and the earth gravity will severely affected so the sea water will rise creating floods "sujirat" over the lands.

While in the second moment, as explained in the surah Al Infițār $82: 3$ as the universe or sky is ripped open, and the stars in the galaxy constellation are scattered messily, it created more devastating catastrophic event. The seawater not only rise, but sprouting up "fujirat". Seawater lost to the universe as the earth gravity no longer has effect compared to the scattered galaxy.

For this two prophecy of the future event, we may learn that there is transfer of energy from the solar system to the seawater. And even gigantic exchange of energy from the galactic dynamics to the ocean water. The earth gravity that holding the seawater from leaving 
the earth surface or rising as massive tides, may become chaotic if the movement of the planets in the solar system and the stars in the galaxies are changing. In the daily ocean tidal variation, we already learn this planetary effect, sun and the moon, on the sea level and sea current. While the dooms day is unknown time of occurrence, as inspired and shown by the two cluster of ayah, the daily variation of moon and sun movement effect to the seawater is a perpetual energy transfer phenomena that should be able to be harnessed for the mankind to sustain life. This is another pointer particularly on the energy transfer matter, that Allah reveals with these oceanic verses.

The following is tabulated form of category of the oceanic verses, subjects and verse location:

\begin{tabular}{|c|c|c|}
\hline Category & Subject & Verses \\
\hline \multirow[t]{3}{*}{ Historical } & Noah & \\
\hline & $\begin{array}{l}\text { Stories of Moses } \\
\text { AS and Khidir AS }\end{array}$ & $\begin{array}{l}\text { QS Al-Kahfi (18): 60; QS Al-Kahfi } \\
\text { (18):61 ; QS Al-Kahfi (18): } 63 \text {; QS Al- } \\
\text { Kahfi (18): } 79\end{array}$ \\
\hline & $\begin{array}{l}\text { Story of Moses AS } \\
\text { and Pharaoh }\end{array}$ & $\begin{array}{l}\text { QS Al-Baqarah (2): } 50 \text {; QS Al-A'râf (7): } \\
\text { 136 ; QS Al-A'rāf (7): } 138 \text {; QS Al-A‘rāf } \\
\text { (7): 163; QS Yūnus (10): } 90 \text {; QS Yûnus } \\
\text { (10): } 92 \text {; QS Țāhā (20): } 77 \text {; QS Țāhā } \\
\text { (20): 78; QS Țāhā (20): } 97 \text {; QS Al- } \\
\text { Syu'arā' (26): } 63 \text {; QS Al-Qaśas (28): } 40 \text {; } \\
\text { QS Al-Dukhān (44): } 24 \text {; QS Al-Dukhān } \\
\text { (44): } 24 \text {; QS Al-Zāriyāt (51): } 40\end{array}$ \\
\hline \multirow[t]{4}{*}{$\begin{array}{l}\text { Physical } \\
\text { Science }\end{array}$} & Layers of the Ocean & QS Al-Nūr (24): 40 \\
\hline & $\begin{array}{l}\text { Darkness in the } \\
\text { Ocean's deep }\end{array}$ & $\begin{array}{l}\text { QS Al-An`Ām (6): } 97 \text {; QS Al-Nūr (24): } \\
40 \text {; QS Al-Naml (27): } 63\end{array}$ \\
\hline & Fire in the sea & Aṭ Ṭūr 52;6 \\
\hline & $\begin{array}{l}\text { Boundary of Two } \\
\text { Oceans and its } \\
\text { Treasure }\end{array}$ & $\begin{array}{l}\text { QS Al-Furqān (25): } 53 \text {; QS Al-Naml } \\
\text { (27): } 61 \text {; QS Fātīr (35): } 12 \text {; QS Al- } \\
\text { Raḥmān (55): 19-22 }\end{array}$ \\
\hline \multirow[t]{2}{*}{ Technological } & Ship Building & QS Hūd \\
\hline & Sailing Vessel & $\begin{array}{l}\text { QS Al-Baqarah (2):164; QS Yūnus } \\
\text { (10):22; QS Ibrāhīm (14):32; QS Al- } \\
\text { Isrā' (17):66; QS Al-Isrā' (17):70; QS Al- } \\
\text { Hajj (22):65; QS Luqmān (31):31 ; QS } \\
\text { Fātị (35):12; QS Al-Syūrā (42):32 ; QS } \\
\text { Al-Jās̄iyah (45):12 ; QS Al-Raḥmān }\end{array}$ \\
\hline
\end{tabular}




\begin{tabular}{|c|c|c|}
\hline & & $(55): 24$ \\
\hline \multirow[t]{5}{*}{ Energy } & $\begin{array}{l}\text { Energy / Heat } \\
\text { within the Ocean }\end{array}$ & QS Aṭ-Ṭūr (52): 6 \\
\hline & Hydrothermal & QS Aț-Ṭūr (52): 6 \\
\hline & $\begin{array}{l}\text { Current } \\
\text { hydrodynamics }\end{array}$ & QS Ar-Ra'd 13:17 \\
\hline & Biofuels & QS Yāsīn 36:80 \\
\hline & $\begin{array}{l}\text { Solar-Lunar } \\
\text { constellation }\end{array}$ & \\
\hline \multirow[t]{2}{*}{ Food } & Meat & QS Al-Mā'idah (5): 96 ; QS Fāṭir (35): 12 \\
\hline & Soft and crunchy & QS Al-Naḥl (16): 14 \\
\hline Services & Sea going vessels & An Nahl 16:14 \\
\hline $\begin{array}{l}\text { Mystery } \\
\text { (Ghaib) }\end{array}$ & & QS Al-An‘Ām (6): 59 \\
\hline \multirow{2}{*}{ Water } & The origin of water & QS An Nūr (24) 43 \\
\hline & $\begin{array}{l}\text { Water as source of } \\
\text { life }\end{array}$ & $\begin{array}{l}\text { QS Al-Baqarah (2):164; QS Ibrāhīm (14): } \\
\text { 32; QS Al-Anbiyā' (21):30; QS Al-Nūr } \\
\text { (24):4-5; QS Al-Furqān (25):54 }\end{array}$ \\
\hline Products & $\begin{array}{l}\text { Cement,Plastic, } \\
\text { polyester, and any } \\
\text { other petrochemical } \\
\text { products,Jewelry; }\end{array}$ & An Naḥl 16:14 \\
\hline \multirow[t]{2}{*}{ Learning } & $\begin{array}{l}\text { Seeking ocean } \\
\text { abundance with } \\
\text { sabar and syukur }\end{array}$ & $\begin{array}{l}\text { QS Al-Isrā' (17):66 ; QS Luqmān } \\
\text { (31):31; QS Fâțir (35):12; QS Al-Jāsiyah } \\
\text { (45):12 }\end{array}$ \\
\hline & $\begin{array}{l}\text { Ocean water } \\
\text { insufficient to } \\
\text { express Allah's } \\
\text { Knowledge }\end{array}$ & $\begin{array}{l}\text { QS Al-Kahfi (18): } 109 \text {; QS Luqmān } \\
\text { (31): } 27\end{array}$ \\
\hline \multirow[t]{2}{*}{ Prophecy } & $\begin{array}{l}\text { Environmental } \\
\text { corruption; } \\
\text { Corrupted and } \\
\text { Calamity in the } \\
\text { Ocean }\end{array}$ & $\begin{array}{l}\text { QS Al-An‘Ām (6): } 63 \text {; QS Al-Isrâ' (17): } \\
67 \text {; QS Al-Isrā' (17): } 69 \text {; QS Al-Rūm } \\
\text { (30): } 41\end{array}$ \\
\hline & $\begin{array}{l}\text { Ocean Condition as } \\
\text { part of Qiyāmah's } \\
\text { Episodes Prophecy }\end{array}$ & $\begin{array}{l}\text { Qiyāmah Episode 'n' : QS At-Takwīr } \\
\text { (81): } 6 \\
\text { Qiyāmah Episode 'n' +1 : QS Al-Infițār } \\
\text { (82): } 3\end{array}$ \\
\hline
\end{tabular}

Table 4: Categorization of Oceanic Verses

The two seas may be sitting side-by-side in small scale or in super scales, or the two seas may be sitting one-on-top of another, in small or large scales. The barrier is a phenomenon that can be 
physicals (temperature, density, salinity, luminance, pressure, etc), chemicals (Oxygen / Carbon dioxide contents, etc.), biological (habitat, species, etc.), cultural (global meeting junction between travelling sea traders), economical (trading hub port, exchange market, etc), and political (geopolitics of outpost overseeing two meeting oceans).

Thank you to Mr. Agus Sulaiman Djamil as a resource person who gave much material for this article

\section{Conclusion}

The study concludes that oceanic verses in the Quran cover a broad range of subjects, from the declaration of the greatness of Allah and prophecies for the future and hereafter, to pragmatic application in food and sustainable energy sustenance. Ontology and categorization of the oceanic verses can be used as an initial stepping stone to further study and build a new Islamic Marine Knowledge discipline. Despite being revealed centuries ago, the verses are relevant as a resolution for modern civilization's biggest challenges. They encourage humankind to gain the benefit of the subjected ocean to live sustainably. Finally, There are pointers in these oceanic verses toward the technological solution for existing and coming of humankind's problems, which Muslims may use this divine guidance ultimately.

\section{References}

'Abbas, I. (2012). Tafsir Ibn 'Abbas (Mokrane Guezzou (Ed.)). Royal Aal al-Bayt Institute for Islamic Thought.

Al-jalalayn. (2012). Tafsir al-Jalalayn. Royal Al al-Bayt Institute for Islamic Thought.

Audah, A. (1992). Konkordansi Al Qur'an. Litera Antar Nusa. 
Badawi, E. M., \& Haleem, M. A. (2008). Arabic-English Dictionary of Qur'anic Usage, in Handbook Of Oriental Studies Handbuch Der Orientalistik Section One, The Near And Middle East (Aaltenmuller (Ed.); 8th ed.). Koninklijke Brill NV.

Dagobert, R. D. (1976). Dictionary of Philosophy, Adam andCompany.

Djamil, A. S. (2004). Al-Quran dan Lautan. Arasy.

Dukes, K. (2011). Quranic Arabic Corpus. Retrieved from http://corpus.quran.com/.

Engel, L. (1979). Laut. Jakarta: Pustaka TIME-LIFE.

Gruber, T. R. (1995). Toward principles for the design of ontologies used for knowledge sharing, published in International Journal of HumanComputer Studies. 43(4-5), 907-928.

International, S. (1997). The Quran: Arabic Text with Corresponding English Meanings, Almunatada Alislami. Abul Qasim Publishing House.

Obitko, M. (2007). Translations between Ontologies in Multi-Agent Systems. Department of Cybernetics.

http://keg.vse.cz/_slides/obitko-2007.pdf

Shihab, M. Q. (1997). Mukjizat Al-Quran: Ditinjau dari Aspek Kebahasaan, Aspek Ilmiah, dan Pemberitaan Gaib. MizanPustaka.

Talbot, F. H., \& Stevenson, R. E. (1991). The Encyclopedia of the Earth: Oceans and Islands. Popular Culture Ink.

Yusoh, Y., \& Muhammad, A. (2012). Falsafah Ilmu dalam Al Quran; Ontology, Epistemology dan Aksiologi. Penerbit UTM Press. 